\title{
Jakość w lutowaniu twardym i lutospawaniu - kwalifikowanie technologii i personelu, metody badań
}

\author{
The quality of brazing and braze welding \\ - qualification of technology and personnel, test methods
}

\section{Streszczenie}

Lutowanie twarde jak i lutospawanie w terminologii norm dotyczących systemów jakości jest zaliczane do procesów specjalnych, których wynik końcowy nie jest pewny. Ograniczenie tej niepewności u wytwórcy wyrobów lutowanych stanowi podstawę wymagań technicznych i jakościowych dla takich wyrobów. W artykule omówiono stan międzynarodowych i krajowych przepisów oraz norm z zakresu wymagań dotyczących planowania i sterowania jakością w produkcji wyrobów lutowanych lutami twardymi i lutospawanych. Obejmują one: kwalifikowanie technologii, personelu (nadzoru i wykonawców), metody stosowanych badań niszczących i nieniszczących połączeń oraz klasyfikację niezgodności lutowniczych i sposób ustalania poziomów jakości połączeń.

Słowa kluczowe: lutowanie twarde; lutospawanie; kwalifikowanie technologii; kwalifıkowanie personelu; metody badań jakości; niezgodności lutownicze

\section{Abstract}

Brazing and braze welding in the terminology of standards for quality systems are classified as special processes, where the final result is not certain. Reducing this uncertainty to the manufacturer of brazed is the basis of technical requirements and quality standards for such products. The article discusses the state of international and national regulations and standards for the requirements planning and quality control in the production of brazed and braze welded details. These include: qualification of personnel (supervisors and contractors), methods used for destructive and non-destructive testing of joints and classification of brazing imperfections and method of determining levels of joint quality.

Keywords: brazing; braze welding; qualification of technology; qualification of personnel; quality test method; brazing imperfections

\section{Wstęp}

Wytwórcy stosujący lutowanie twarde w procesach produkcyjnych odpowiedzialnych wyrobów powinni posiadać udokumentowaną i uznaną technologię lutowania, a także odpowiednio wykwalifikowany personel nadzorujący, wykonawczy oraz kontrolujący jakość połączeń. Jest to wymóg odnoszący się w przepisach i normach dotyczących systemów jakości do procesów specjalnych tj. procesów, których wynik końcowy nie jest pewny i zależy od wielu czynników. Lutowanie twarde, analogicznie jak spawanie i zgrzewanie zaliczane są do tej grupy procesów. Podejmowane w powyższym zakresie działania Europejskiej Federacji Spawalniczej (European Welding Federation - EWF) i jej Autoryzowanych Ośrodków Krajowych (ANB - Autorized National Body) oraz opracowane normy europejskie stanowią wiarygodną bazę do planowania i sterowania jakością w procesach lutowania. Niniejszy artykuł stanowi kontynuację dotychczaso- wych krajowych publikacji z zakresu problematyki jakości w lutowaniu twardym $[1 \div 4]$. Ma on na celu omówienie i uaktualnienie obowiązujących przepisów oraz poszerzenie ich interpretacji i zastosowania w praktyce przemysłowej w oparciu o własne doświadczenia. Należy bowiem mieć na uwadze fakt, że wzrastające zastosowanie technologii lutowania w przemyśle niesie ze sobą również tego typu problemy do rozwiązania.

\section{Uznawanie (kwalifikowanie) technologii}

Ogólne i podstawowe zasady uznawania, czyli weryfikacji technologii lutowania twardego czy spełnia ona wymagania stawiane uzyskiwanym połączeniom, są zawarte w PN-EN 13134:2004 [5]. W przeciwieństwie do norm dotyczących

Dr inż. Andrzej Winiowski, prof. nzw. w IS; dr inż. Dawid Majewski - Instytut Spawalnictwa Gliwice.

Autor korespondencyjny/Corresponding author: andrzej.winiowski@is.gliwice.pl 
technologii spawania norma ta nie doczekała się dotychczas nowelizacji. Przedstawiono w niej zasady tworzenia Instrukcji Technologicznych Lutowania Twardego (BPS - Brazing Procedure Specification) oraz procedury uznawania przedstawionych w nich technologii lutowania. Uznawanie to może odbywać się $w$ jeden $z$ trzech sposobów: na podstawie złożonych przez wytwórcę udokumentowanych wyników badań, po przedłożeniu wyników uznania technologii dokonanego przez inną jednostkę egzaminacyjną lub też w wyniku przeprowadzenia badania technologii. Dokumentem uznania jest Protokół Uznania Technologii Lutowania Twardego (BPAR - Brazing Procedure Approval Record), składający się z trzech części: świadectwa uznania technologii, uznanej technologii (wg BPS) i wyników badań. Norma nie definiuje ściśle kto może być egzaminatorem lub jednostką egzaminującą dla uznawania technologii, nadmienia tylko, że jeśli jest to wymagane, może to być jednostka notyfikowana lub uznana za trzecia stronę. W praktyce klient wytwórcy - odbiorca wyrobów lutowanych może przedstawić w tej sprawie swoje wymagania.

Zgłaszając technologię do uznania wytwórca powinien przedstawić wstępną Instrukcję Technologiczną Lutowania Twardego (pBPS). Obie strony egzaminator i wytwórca powinny uzgodnić i udokumentować zakres badań, ilość próbek, kryteria akceptacji oraz zakres uznania. Minimalny, wymagany zakres badań obejmuje badania wizualne wg normy PN-EN 12799:2003 [6] i badania metalograficzne wg normy PN-EN 12797:2002 [7]. Najczęściej stosowane badania metalograficzne w przypadku złączy lutowanych to badania makrostruktur (pow. do 30x) lub badania na pograniczu makro i mikrostruktur (pow. do kilkudziesięciu razy). Dodatkowe badania nieniszczące i niszczące przeprowadza się wg powyższych norm w zależności od wymagań stawianych połączeniom lutowanym. PN-EN 13134:2004 nie określa szczegółowo zakresu uznania, jak podaje to np. norma dotycząca egzaminowania lutowaczy i operatorów lutowania twardego PN-EN ISO 13585:2012 [8]. Dopuszcza ona jedynie dla uniknięcia podwójnych badań, tam gdzie jest to możliwe, ustalenie zakresu uznania przykładowo: dla materiałów podstawowych, klasy spoiw czy też wymiarów geometrycznych złączy. Jest tu więc pozostawiona pewna dowolność.

Uznanie technologii lutowania twardego, stosowanej zgodnie z Instrukcją Technologiczną Lutowania Twardego (BPS), jest ważne bezterminowo.

\section{Badania jakości połączeń i niezgodności lutownicze}

Jak wspomniano powyżej rodzaje badań, metody i kwalifikacje personelu wykonującego badania połączeń lutowanych lutami twardymi określono w normach PN-EN 12799: 2003 [6] i PN-EN 12797: 2002 [7]. Pierwsza z nich dotyczy badań nieniszczących połączeń i obejmuje: badania wizualne, ultradźwiękowe, radiograficzne, penetracyjne, szczelności, na obciążenie i termograficzne. Druga norma dotyczy badań niszczących takich jak: na ścinanie, rozciąganie, metalograficznych, twardości, na odrywanie i zginanie. Obie normy zostały opracowane dość dawno i wymagają nowelizacji celem poszerzenia zakresu badań, uaktualnienia metodyki poszczególnych badań w oparciu o nowe urządzenia, a także rozszerzenia postaci próbek zwłaszcza w badaniach niszczących.

Niezgodności lutownicze zdefiniowano w normie PN-EN ISO 18279:2008 [9], przedstawiając ich rodzaj, kształt i położenie $w$ połączeniach lutowanych. Sklasyfikowano je w sześciu grupach (pęknięcia, pustki, wtrącenia stałe, brak połączenia, niezgodności kształtu i wymiarów oraz niezgodności różnorodne) i zaproponowano kryteria oceny i poziomy jakości dla złączy lutowanych (D - umiarkowany, C - pośredni, B - ostry, A - szczególnie ostry). Autorzy normy zwracają uwagę na ograniczoną możliwość zastosowania tej oceny. Wiadomo bowiem, że w złączach lutowanych występują niezgodności, które są ogólnie, w zależności od wymagań eksploatacyjnych uznawane za szkodliwe w każdym przypadku lub tylko w niektórych przypadkach zastosowań. Określenie wpływu niezgodności lutowniczych na funkcjonowanie złączy w trakcie eksploatacji jest jednak sprawą trudną, gdyż nie prowadzono dotychczas tak szczegółowych badań jak np. dla złączy spawanych. Podjęta w powyższej normie próba określenia poziomów jakości dla złączy lutowanych w oparciu o proponowane granice występowania niezgodności dotyczy jedynie ogólnych zastosowań. Należy je traktować jako propozycje, które mogą być przydatne, gdy brak jest innych szczegółowych przepisów w tym zakresie. Natomiast zaleca się aby wymagania dla prawidłowego funkcjonowania odpowiedzialnych złączy w konstrukcjach i wyrobach lutowanych ustalane były przy wykorzystaniu odpowiednich dokumentów technicznych, np. dokumentacji produkcyjnej lub instrukcji technologicznej wytwarzania.

\section{Kwalifikowanie personelu}

Wykwalifikowany personel jest kluczowym elementem każdego systemu jakości. Dotyczy to także nadzoru, kontroli i bezpośrednich wykonawców połączeń lutowanych. Obowiązujący w Unii Europejskiej, a po porozumieniu z Międzynarodowym Instytutem Spawalnictwa również w krajach członkowskich Instytutu, system kształcenia personelu spawalniczego nie przewiduje specjalizacji z zakresu lutowania dla dozoru i kontroli. Programy szkolenia dozoru (Europejski/Międzynarodowy Inżynier Spawalnik, Europejski/Międzynarodowy Technolog Spawalnik, Europejski/Międzynarodowy Mistrz Spawalnik) oraz kontroli (Europejski Inspektor Spawalniczy) zawierają problematykę lutowania w części wykładowej i praktycznej.

Zgodnie z Rozporządzeniem Ministra Gospodarki z dnia 27 kwietnia 2000 r. w sprawie bezpieczeństwa i higieny pracy przy pracach spawalniczych (Dz. U. 00.40.470 z dnia 19 maja 2000 r.) osoby wykonujące m.in. lutowanie ręczne oraz zmechanizowane i automatyczne - powinny wykazać się co najmniej zaświadczeniem o ukończeniu szkolenia w zakresie określonym w odrębnych przepisach i Polskich Normach. A zatem zaświadczenie ukończenia szkolenia w zakresie lutowania dopuszcza lutowaczy i operatorów do wykonywania prac lutowniczych. Jednak przepisy i normy, o których ogólnikowo mówi Rozporządzenie, nie zostały dotychczas opracowane i panuje w tej dziedzinie duża dowolność. W przypadku wykonywania odpowiedzialnych połączeń lub istnienia wymagań wynikających z wdrożonych systemów jakości, czy też wymagań odbiorców wyrobów lutowanych, przeprowadza się egzaminowanie kwalifikacyjne lutowaczy i operatorów lutowania twardego wg normy PN-EN ISO 13585:2012 [8]. W normie tej zdefiniowano lutowaczy jako osoby, które trzymają i operują ręcznie urządzeniem do nagrzewania obszaru lutowanego, a operatorów jako osoby, które przygotowują złącza i nastawiają urządzenia lutownicze, a przez to mają bezpośredni wpływ na jakość lutowanego złącza.

Kwalifikowanie lutowaczy i operatorów lutowania twardego opiera się na zmiennych zasadniczych, dla których określony jest odpowiedni zakres kwalifikacji. Lutowanie prowadzone poza tym zakresem wymaga przeprowadzenia 
nowego egzaminu kwalifikacyjnego. Podstawowe zmienne zasadnicze to:

- proces lutowania twardego - procesy zdefiniowane w ISO 857-2 [10], o numerach referencyjnych wg ISO 4063 (PN-EN ISO 4063:2011) [11];

- rodzaj wyrobu (blacha lub rura);

- rodzaj złącza (doczołowe lub zakładkowe);

- grupy materiału podstawowego - oznaczenia grup materiałowych wg systemu ISO/TR 15608:2013 [12];

- rodzaj spoiwa do lutowania twardego wg klas w PN-EN ISO 17672:2010 [13];

- sposób dozowania spoiwa (spoiwo podawane na powierzchnie czołowe lub umieszczane przed lutowaniem w szczelinie złącza);

- wymiary (grubość materiału, średnica zewnętrzna rury i długość zakładki);

- kierunek płynięcia spoiwa (poziomy, pionowy z góry w dół lub pionowy z dołu do góry);

- stopień mechanizacji (proces ręczny lub zmechanizowany). Należy podkreślić, że każdy egzamin kwalifikacyjny zwykle kwalifikuje tylko jeden proces lutowania twardego. W zależności od kształtu elementów łączonych norma przewiduje zakres kwalifikacji: blacha lub rura, a w zależności od rodzaju złącza próbnego: złącze zakładkowe lub doczołowe. W celu uproszczenia przedstawienia zakresu kwalifikacji, dla materiałów, ujęto je w klasy i oznaczono je literami od $A$ do $F$, stosując system grupowania wg ISO/TR 15608:2013 [12]. Wykaz ten jest jednak niekompletny. Brakuje przykładowo blach stalowych z pokryciami ochronnymi, oraz zestawów materiałów różnoimiennych jak: spieki narzędziowe - stal, miedź - aluminium, stal - tytan, stal - aluminium itp. W przypadku spoiw do lutowania rodzaj lutu przydzielony do odpowiedniej klasy wg PN-EN ISO 17672:2010 [13], może stanowić kryterium kwalifikacji dla innych rodzajów spoiw w zakresie tej samej klasy. Norma przewiduje również dwa sposoby dozowania spoiwa: na powierzchnie czołowe (do szczeliny złącza) oraz umieszczenie spoiwa przed lutowaniem wewnątrz szczeliny lub u jej wylotu. Sposób dozowania na powierzchnie czołowe, realizowany ręcznie lub w sposób zmechanizowany, obejmuje zakres kwalifikacji dla obydwu sposobów dozowania. Grubość lutowanego materiału, średnica zewnętrzna rur i długości zakładki złącza też posiadają sprecyzowane zakresy kwalifikacji. Dla grubości materiału jest to ustalony stosunkowo szeroki zakres wymiarów, natomiast w przypadku średnicy zewnętrznej rury i długości zakładki złącza zakres kwalifikacji obejmuje wymiar zastosowany w złączu egzaminacyjnym lub wszystkie wymiary do wielkości tego wymiaru. W przypadku złączy próbnych elementów o różnej średnicy zewnętrznej i grubości zakres kwalifikacji obejmuje wymiary od najmniejszego do największego zastosowanego wymiaru. Norma wyróżnia trzy kierunki płynięcia lutu: poziomy, pionowy z góry na dół i pionowy z dołu do góry. Lutowanie twarde z zastosowaniem jednego kierunku płynięcia spoiwa może kwalifikować lutowanie z zastosowaniem jednego lub innych kierunków. I tak kierunek poziomy - kwalifikuje poziomy i pionowy z góry na dół, pionowy z góry na dół - pionowy z góry na dół, pionowy z dołu do góry - kwalifikuje wszystkie kierunki płynięcia. Lutowanie wykonane w sposób ręczny kwalifikuje lutowanie zmechanizowane, ale nie odwrotnie.

Lutowanie twarde złącza egzaminacyjnego powinno się odbyć w obecności egzaminatora lub przedstawiciela jednostki egzaminującej, który jednocześnie weryfikuje wyniki egzaminu. Egzamin lutowaczy i operatorów lutowania twardego powinien przebiegać zgodnie z Instrukcją Technologiczną Lutowania (BPS lub pBPS), przygotowaną wg PN-EN 13134:2004 [5].
Dla każdego wykonanego złącza próbnego należy przeprowadzić badania wizualne wg PN-EN 12799:2003 [6] oraz jedno lub więcej z następujących badań: ultradźwiękowe, radiograficzne, wytrzymałości na odrywanie, wytrzymałości na zginanie lub badania metaloznawcze makroskopowe. Podczas badań wizualnych może być konieczne rozcięcie złącza, umożliwiające przeprowadzenie oględzin od strony wewnętrznej i dlatego to badanie może mieć charakter badania niszczącego. Badania niszczące powinny być przeprowadzone zgodnie z PN-EN 12797:2002 [7]. Niezgodności wykryte za pomocą powyższych badań w złączach egzaminacyjnych powinny być oceniane zgodnie z PN-EN ISO 18279:2008 [9]. Lutowacz lub operator lutowania twardego zdobywa kwalifikacje, jeśli niezgodności mieszczą się w poziomie jakości B wg ww. normy, a żadna niezgodność nie występuje na całej długości złącza.

Okres ważności uprawnień lutowacza lub operatora wynosi podobnie jak w przypadku spawaczy 3 lata i może być przedłużony na kolejne 3 lata jeżeli połączenia lutowane w zakresie posiadanych uprawnień są wykonywane przez lutowacza lub operatora w sposób ciągły (dopuszcza się przerwę do 6 miesięcy) i wykazują wymaganą jakość. Powinno to być potwierdzane na świadectwie co 6 miesięcy podpisem osoby odpowiedzialnej ze strony pracodawcy, a dokumentacja z badań elementów lutowanych, pochodząca z okresu 6 miesięcy poprzedzających koniec terminu ważności uprawnień, powinna być przechowywana wraz ze świadectwem.

Świadectwo egzaminu kwalifikacyjnego lutowacza/ operatora jest dokumentem potwierdzającym, że lutowacz lub operator lutowania twardego zdał egzamin z wynikiem pozytywnym. Świadectwo powinno zawierać szczegółowe dane dotyczące zmiennych procesowych, warunków przeprowadzania testu oraz część potwierdzającą kwalifikacje. Świadectwa te są zbliżone pod względem formy do świadectw (certyfikatów) spawaczy.

Oznaczenie egzaminu (uprawnień) lutowacza obejmuje poniższe pozycje w podanej kolejności:

a) numer niniejszej normy,

b) zmienne zasadnicze:

- numer procesu lutowania twardego zgodnie z PN-EN ISO 4063:2011 [11],

- rodzaj wyrobu: rura $(T)$ lub blacha $(P)$,

- rodzaj złącza: złącze doczołowe (B), złącze zakładkowe (0) lub złącze teowe $(T)$,

- grupa/grupy materiału podstawowego wg ISO/TR 15608:2013 [12],

- rodzaj spoiwa do lutowania twardego zgodnie z PNEN ISO 17672:2010 [13],

- sposób dozowania spoiwa do lutowania twardego: przez podawanie na powierzchnie czołowe (FF) lub przez umieszczenie przed lutowaniem (PP),

- wymiary (grubość materiału, średnica zewnętrzna rury i długość zakładki),

- kierunek płynięcia spoiwa: płynięcie w kierunku poziomym $(\mathrm{H})$, płynięcie w kierunku pionowym z dołu do góry (VU) lub płynięcie w kierunku pionowym z góry na dół (VD).

Przykład: ISO 13585 - 912 T O D CuP 280 FF t1,0 D28 L10 H

lutowanie ręczne płomieniowe (912), rury (T), połączenie zakładkowe (0), miedź z grupy 31 wg ISO/TR 15608 (D), lut typu Ag-CuP (CuP 280), podawany na powierzchnie czołowe $(\mathrm{FF})$, grubość materiału $1,0 \mathrm{~mm}$, średnica zewnętrzna rury 28 mm (D28), długość zakładki 10 mm (L10), płynięcie lutu poziome $(\mathrm{H})$.

Oznaczenie egzaminu operatora oprócz nr normy zawiera nr procesu lutowania twardego zgodnie z PN-EN ISO 4063:2011 [11], przykłady: ISO 13585 - 921 lub ISO 13585 - 916 
lutowanie piecowe (921), lutowanie indukcyjne (916).

\section{Lutospawanie}

Lutospawanie płomieniowe, łukowe, laserowe, definiowane jako lutowanie twarde (niekapilarne) z zastosowaniem techniki spawania, nie jest objęte osobnymi normami z zakresu uznawania technologii, badań połączeń i oceny ich jakości, a także kwalifikowania personelu wykonawczego. W PN-EN 13134:2000 [5] dotyczącej uznawania technologii lutowania twardego nie uwzględniono metod lutospawania łukowego, laserowego i elektronowego, nazywanych również często lutowaniem twardym łukowym (lutowanie twarde TIG, MIG/MAG, plazmowe), laserowym i elektronowym. Nie zamieszczono tam też charakterystycznych zmiennych zasadniczych dla tych technologii (tabl. A.1). Opracowanie zatem w przypadku konieczności Instrukcji Technologicznej pBPS (BPS), a następnie Protokołu Uznania BPAR dla tych procesów lutospawania będzie wymagać sięgnięcia po wzorce formularzy, zalecane do kwalifikowania technologii spawania powyższymi metodami. Badania i ocena jakości połączeń lutospawanych odbywać się powinny wg norm dotyczących złączy lutowanych, a więc: PN-EN 12799:2003,
PN-EN 12797:2002 i PN-EN ISO 18279:2008 [6,7,9].

Egzaminowanie kwalifikacyjne lutospawaczy łukowych oraz operatorów lutospawania łukowego i laserowego może się natomiast odbywać wg zasad przedstawionych w normie PN EN ISO 13585:2012 [8]. Przykłady oznaczenia takiego egzaminu:

a) dla lutospawaczy MIG/MAG:

ISO 13585 - 973 P O EG HDG st Cu541 FF t1,2 H

lutospawanie MIG/MAG (973), blachy $(P)$, złącza zakładkowe (O), stale (st) niestopowe i stopowe, galwanicznie (EG) i zanurzeniowo (HDG) cynkowane dla motoryzacji, spoiwo typu Cu-Si-Mn (Cu 541), podawane na powierzchnie czołowe $(\mathrm{FF})$, grubość blach 1,2 mm (t1,2), płynięcie spoiwa w poziomie $(\mathrm{H})$.

b) dla operatorów:

- lutospawania łukowego MIG/MAG: ISO 13585 - 973,

- lutospawania łukowego TIG: ISO 13585 - 974,

- lutospawania plazmowego: ISO 13585 - 975,

- lutospawania laserowego: ISO 13585 - 976,

- lutospawania elektronowego: ISO 13585 - 977.

Należy również podkreślić, że brak jest szczegółowych przepisów odnośnie szkolenia lutospawaczy i operatorów lutospawania. Odbywa się ono praktycznie w oparciu o autorskie programy ośrodków szkoleniowych.

\section{Uwagi końcowe}

Analizując dotychczasowe normy i przepisy dotyczące zapewnienia jakości w procesach lutowania twardego należy stwierdzić, że istniejące i stosowane normy z zakresu uznawania (kwalifikowania) technologii lutowania twardego (PN-EN 13134:2004), badań niszczących i nieniszczących połączeń lutowanych (PN-EN 12799:2003 i PN-EN 12797: 2002) oraz norma dotycząca niezgodności lutowniczych i poziomów jakości złączy (PN-EN ISO 18279:2008) wymagają obecnie nowelizacji. Pierwsza z nich tj. norma z zakresu uznawania technologii wymaga uwzględnienia nowych metod lutowania i lutospawania, rozszerzenia zmiennych procesów, a także uściślenia zakresów uznania np. w sposób kompatybilny z nową normą, dotyczącą egzaminowania lutowaczy i operatorów (PN EN ISO 13585:2012). Dwie następne wymienione powyżej normy, dotyczące badań połączeń lutowanych wymagają z kolei poszerzenia zakresu badań, uzupełnienia metodyki poszczególnych badań z uwzględnieniem nowych urządzeń, a także rozszerzenia postaci próbek, zwłaszcza do badań niszczących. Trzecia z przedstawionych norm wymaga uściślenia błędnego w niektórych przypadkach nazewnictwa niezgodności lutowniczych, a także weryfikacji kryteriów oceny jakości połączeń i ich klasyfikacji.

Wprowadzenie normy PN EN ISO 13585:2012 w znacznym stopniu uregulowało problematykę egzaminowania personelu wykonawczego w dziedzinie lutowania twardego. Świadectwa kwalifikacji lutowaczy nareszcie są pod względem formy zbliżone do świadectw z egzaminu kwalifikacyjnego spawaczy wg wieloarkuszowej normy PN-EN ISO 9606 [14]. PN EN ISO 13585:2012 obejmuje również operatorów lutowania oraz może być stosowana dla lutospawaczy i operatorów lutospawania, czego nie uwzględniały nieaktualne już, stare normy: PN-EN 13133:2002 (dotyczyła egzaminowania tylko lutowaczy gazowych ręcznych) i PN-EN 1418:2000 (dotyczyła egzaminowania operatorów spawania i zgrzewania), ani też nowa, aktualnie obowiązująca norma dotycząca egzaminowania operatorów spawania i zgrzewania EN ISO 14732:2013 [15].

Należy jednak zwrócić uwagę na fakt, że w wielu przypadkach do prowadzania procesów lutowniczych, a zwłaszcza do wykonywania mniej odpowiedzialnych złączy przez drobnych wytwórców szerokiego asortymentu wyrobów lutowanych, czy też prac lutowniczych w utrzymaniu ruchu zakładów przemysłowych, wystarczy zaświadczenie ukończenia przez lutowacza kursu (szkolenia) z zakresu lutowania. Spełnia ono wymagania dopuszczeniowe Rozporządzenia Ministra Gospodarki z 2000 r. w sprawie BHP przy pracach spawalniczych.

\section{Literatura}

[1] T. Kuzio: Uznana technologia i kompetentny personel podstawą zapew-

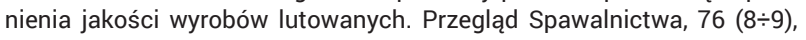
str. 71-73, 2004

[2] J. Nowacki, M. Chudziński, P. Zmitrowicz: Dokumentowanie i uznawanie technologii lutowania, Przegląd Spawalnictwa, 78(11) str. 26-31, 2006

[3] J. Nowacki, M. Chudziński, P. Zmitrowicz: Lutowanie w budowie maszyn, WNT, Warszawa 2007

[4] T. Piwowarczyk, Z. Mirski, A. Winiowski, H. Drzeniek: Dokumentowanie procesu lutowania oraz egzaminowanie lutowaczy i operatorów lutowania twardego wg PN-EN ISO 13585:2012. Przegląd Spawalnictwa, 85 (9) str. 55-63, 2013.

[5] PN-EN 13134:2004 "Lutowanie twarde - Uznawanie technologii".

[6] PN-EN 12799:2003 "Lutowanie twarde - Badania nieniszczące złączy lutowanych na twardo".

[7] PN-EN 12797:2002 „Lutowanie twarde - Badania niszczące złączy lutowanych na twardo".

[8] PN-EN ISO 13585:2012 "Lutowanie twarde - Kwalifikowanie lutowaczy i operatorów lutowania twardego".

[9] PN-EN ISO 18279:2008 „Lutowanie twarde - Niezgodności w złączach lutowanych na twardo".

[10] ISO 857-2 „Welding and allied processes - Vocabulary - Part 2: Soldering and brazing processes and related terms".

[11] PN-EN ISO 4063:2011 „Spawanie i procesy pokrewne - Nazwy i numery procesów".

[12] ISO/TR 15608: 2013 „Welding - Guidelines for a metallic materials grouping system".

[13] PN-EN ISO 17672:2010 "Lutowanie twarde - Spoiwa”.

[14] PN-EN ISO 9606 „Egzamin kwalifikacyjny spawaczy - Spawanie” cz. 1, 5.

[15] PN-EN ISO 14732:2013 „Personel spawalniczy - Egzaminowanie operatorów i nastawiaczy zmechanizowanego i automatycznego spajania materiałów metalowych". 